\title{
Daily Photosynthesis, Water Relations, and Ion Concentrations of Euonymus Irrigated with Treated Wastewater
}

\author{
María José Gómez-Bellot ${ }^{1}$, Pedro Antonio Nortes, \\ María Fernanda Ortuño, and María Jesús Sánchez-Blanco \\ Department of Irrigation, Centro de Edafología y Biología Aplicada del \\ Segura (CSIC), P.O. Box 164, E-30100 Murcia, Spain
}

\author{
Karoline Santos Gonçalves \\ Universidade Estadual Paulista, Campus de Botucatu, 18610-307 Botucatu- \\ SP, Brazil
}

\section{Sebastián Bañón \\ Department of Agricultural Production, Universidad Politécnica de Cartagena (UPCT), E-30203 Cartagena, Spain}

Additional index words. fluorescence, gas exchange, ornamental plants, plant nutrition, salinity

\begin{abstract}
Euonymus japonica Thunb. (euonymus) plants were submitted for 9 months to two irrigation treatments using water from different sources: a control $(C)$ water with electrical conductivity (EC) less than $1.2 \mathrm{dS} \cdot \mathrm{m}^{-1}$ and reclaimed wastewater $(\mathrm{RW})$ with $\mathrm{EC} \approx 4 \mathrm{dS} \cdot \mathrm{m}^{-1}$. At the end of the experiment, no differences in the total dry weight were observed between treatments, whereas the leaf dry mass increased (to the detriment of the root part in $R W$ plants). Throughout the day, the stem water potential $\left(\Psi_{\text {stem }}\right)$ of the $R W$ plants was lower than in $C$, whereas stomatal conductance $\left(g_{S}\right)$ was slightly reduced in $R W$ from $0800 \mathrm{HR}$ to $1200 \mathrm{HR}$, but no significant variation in photosynthesis $\left(P_{n}\right)$ or energy conversion efficiency $\left(F^{\prime}{ }_{v} / F^{\prime}{ }_{m}\right)$ in photosystem II was detected through the effect of salinity. Gas exchange and fluorescence showed a tendency to increase after midday in plants treated with $R W$. The photosynthetic behavior and fluorescence of $R W$ plants may have been related to the nitrogen and chlorophyll content of the leaves, confirming the resistance of the photosynthetic mechanism to salinity in this species in these conditions. The toxic effects produced by high concentrations of boron (B), sodium $\left(\mathrm{Na}^{+}\right)$and chloride $\left(\mathrm{Cl}^{-}\right)$were offset by the effect of other ions like magnesium $\left(\mathrm{Mg}^{2+}\right)$, potassium $\left(\mathrm{K}^{+}\right)$, and phosphorus $(\mathrm{P})$ in plants irrigated with $\mathrm{RW}$, thus improving their physiological status without decreasing their ornamental value.
\end{abstract}

In recent years, the increase in crop areas and associated water demands have led to a decrease in fresh water availability. In arid and semiarid areas, where there is an increasing shortage of water, irrigation is fundamental for agricultural development (Feigin et al., 1991). Alternative sources of water such as treated wastewater are therefore required to satisfy the needs of crops and its use is gradually becoming a common practice worldwide (Angelakis et al., 1999).

One of the advantages of treated wastewater is that it acts as an important source of nutrients for crop production (Jimenez-Cisneros, 1995; Kiziloglu et al., 2007) so that it may be possible to reduce fertilizer application when treated wastewater is used (Gori et al., 2000;

Received for publication 6 June 2014. Accepted for publication 24 July 2014.

We are grateful for the financial aid received from the Spanish Ministry of Science and Innovation (AGL 2011-30022-C02-01-02) and Fundación Séneca (15356/PI/10).

${ }^{1}$ To whom reprint requests should be addressed; e-mailmjgb@cebas.csic.es. laboratory test results, the data are often incomplete for assessing irrigation quality because they are oriented to the "human impact factor" rather than performance (Duncan et al., 2009). As a consequence, it is necessary to take precautions before reusing wastewater (Angelakis et al., 1999).

One of the main factors that determine the suitability of low-quality water for irrigation is its salinity. Among the many effects, salinity generates the decrease in the $\psi_{\mathrm{S}}$ of the medium, which, as a consequence, increases the difficulty of the plant to take water from the medium (Neumann, 1997). In saline conditions, reductions in the levels of $\mathrm{CO}_{2}$ assimilation have been related, among others, to partial stomatal closure, decreases in the photosynthetic pigments, and changes in the ion concentration of leaves (Demetriou et al., 2007). Furthermore, such physiological responses in plants are also subject to the daily changes in environmental factors such as atmospheric temperature, light, or humidity.

From this point of view, the study of the daily patterns of leaf water relations and gas exchange activity is a good physiological approximation for analyzing the optimum water use by plants (Hsiao, 1993) and can provide basic information on plant responses to irrigation. Moreover, there are recent studies that use other less common methods such as infrared thermography to indirectly determine the plant water status. The physiological basis of this methodology is the decrease in energy dissipation caused by transpiration resulting from the stomatal closure in plants under water stress, the consequence of which is an increase in leaf temperature (Costa et al., 2012; Jackson et al., 1981; Jones et al., 2002).

Euonymus japonica Thunb. (euonymus) is a popular shrub from Japan, which grows naturally in coastal zones where salt accumulates in soils and is widely used as an ornamental plant. The aim of this work was the daily characterization of the water status of euonymus plants irrigated with good-quality water and treated wastewater with a high salinity level to determine the physiological behavior in this plant. We studied the daily and seasonal gas exchange parameters, water relations, and canopy temperature as well as leaf ion accumulation, photosynthetic pigments, and plant growth.

\section{Material and Methods}

with controversial results, probably as a result of the different cultivation techniques used, environmental characteristics, and the different species studied (Acosta-Motos et al., 2014; Bañón et al., 2011; Gori et al., 2000; Schuch, 2005).

The need to obtain ornamental plants of a high quality entails the proper management of irrigation (Weber et al., 1996) and a careful evaluation of its effect on plants. The chemical composition of treated wastewater varies according to the treatment process, source of waters, location, and time of year (Niu and Cabrera, 2010). Although some water reclamation treatment facilities offer periodic
Plant material and growth conditions. The experiment was conducted in 1-year-old Euonymus japonica plants $(\mathrm{n}=80)$ in $2.5-\mathrm{L}$ polyethylene pots (diameter $17 \mathrm{~cm}$, height $14 \mathrm{~cm}$ ) containing a substrate of coconut fiber, black and blond peat, and perlite (8:7:1) amended with $2 \mathrm{~g} \cdot \mathrm{L}^{-1}$ of Osmocote Plus [14: 13:13 nitrogen $(\mathrm{N}), \mathrm{P}, \mathrm{K}$ plus microelements]. On 9 Nov. 2011, the pots were placed in a plastic greenhouse in the CEBAS experimental farm located in Santomera (Murcia, Spain) equipped with a cooling system. The microclimatic conditions recorded with a Vaisala probe (HMP45C) during the experimental 
period showed air temperature, relative humidity, and vapor pressure deficit values of $\approx 22^{\circ} \mathrm{C}, 64 \%$, and $1.3 \mathrm{KPa}$, respectively. The pots were randomly placed in two independent irrigation lines.

The treatments were started on 18 Nov. 2011 and for 36 weeks the plants were irrigated with water from two different sources: $\mathrm{C}$ (to $100 \%$ water-holding capacity, EC less than $1.2 \mathrm{dS} \cdot \mathrm{m}^{-1}$, leaching $15 \%$ of the applied water) and RW (EC: $4 \mathrm{dS} \cdot \mathrm{m}^{-1}$, leaching $40 \%$ of the applied water to avoid excessive accumulation of salts in the substrate) from a sewage treatment plant in Campotejar (Murcia, Spain). The wastewater treatment plant applies a conventional activated sludge process followed by ultraviolet application for the tertiary treatment. The experimental period ended on 31 July 2012. The height of all the plants at the beginning of the experiment was similar, $\approx 40$ to $45 \mathrm{~cm}$.

One drip nozzle, delivering $2 \mathrm{~L} \cdot \mathrm{h}^{-1}$ per pot, was connected to two spaghetti tubes, irrigated daily and the duration of each irrigation episode depended on the season, climatic conditions, and plant development. Water consumption was measured gravimetrically throughout the experimental period and was determined from the difference in weights (weight after irrigation, when drainage stopped, and weight before rewatering).

Water analyses. The inorganic solute content, $\mathrm{pH}$, and $\mathrm{EC}$ of the irrigation waters

Table 1. Physicochemical analyses for the irrigation treatments. ${ }^{\mathrm{z}}$

\begin{tabular}{lcc}
\hline $\begin{array}{l}\text { Physicochemical } \\
\text { analyses }\end{array}$ & $\mathrm{C}$ & $\mathrm{RW}$ \\
\hline $\mathrm{pH}$ & 7.97 & 7.77 \\
$\mathrm{EC}$ & 0.87 & 4.02 \\
$\mathrm{Cl}\left(\mathrm{mg} \cdot \mathrm{L}^{-1}\right)$ & 69.5 & 688.1 \\
$\mathrm{Na}\left(\mathrm{mg} \cdot \mathrm{L}^{-1}\right)$ & 52.07 & 586.2 \\
$\mathrm{~B}\left(\mathrm{mg} \cdot \mathrm{L}^{-1}\right)$ & 0.09 & 0.97 \\
$\mathrm{Ca}\left(\mathrm{mg} \cdot \mathrm{L}^{-1}\right)$ & 94.21 & 214.8 \\
$\mathrm{~K}\left(\mathrm{mg} \cdot \mathrm{L}^{-1}\right)$ & 3.39 & 51.15 \\
$\mathrm{Mg}\left(\mathrm{mg} \cdot \mathrm{L}^{-1}\right)$ & 41.87 & 177.3 \\
$\mathrm{P}\left(\mathrm{mg} \cdot \mathrm{L}^{-1}\right)$ & 0.22 & 1.62 \\
\hline
\end{tabular}

${ }^{2}$ Data are values from samples collected 8 weeks after applying the treatments. electrical conductivity; $\mathrm{Cl}=$ chloride; $\mathrm{Na}=$ sodium; $\mathrm{B}=$ boron; $\mathrm{Ca}=$ calcium; $\mathrm{K}=$ potassium; $\mathrm{Mg}=$ magnesium; $\mathrm{P}=$ phosphorous. one on each side of every pot. Plants were

$\mathrm{C}=$ control; $\mathrm{RW}=$ reclaimed wastewater; $\mathrm{EC}=$

were assessed in Jan. 2012, 8 weeks after beginning the treatments. The samples were collected in glass bottles and stored at $5{ }^{\circ} \mathrm{C}$ before being processed for chemical analysis. The $\mathrm{pH}$ was measured with a Cryson-507 pH-meter (Crisom Instruments S.A., Barcelona, Spain); EC and total dissolved solids were determined using the multirange equipment, Cryson-HI8734 (Crisom Instruments S.A., Barcelona, Spain); the concentrations of macronutrients $\mathrm{Na}^{+}, \mathrm{K}^{+}, \mathrm{P}$, calcium $\left(\mathrm{Ca}^{2+}\right)$ and $\mathrm{Mg}^{2+}$, and the micronutrient $\mathrm{B}$ were determined by inductively coupled plasma optical emission spectrometer (ICP-ICAP 6500; DUO Thermo, U.K.). $\mathrm{Cl}^{-}$were analyzed by ion chromatography with a Metrhom Chromatograph (Switzerland).

Growth parameters and mineral content. At the end of the experiment, the substrate was gently washed from the roots of three plants per treatment. Then, the plants were divided into shoots (leaves and stems) and roots. These were then oven-dried at $80{ }^{\circ} \mathrm{C}$ until they reached a constant weight to measure the respective dry weights (DWs). Leaf number was counted directly and leaf area $\left(\mathrm{cm}^{2}\right)$ was determined in the same plants using a leaf area meter (Delta-T; Devices Ltd., Cambridge, U.K.). The height was also determined in 10 plants per treatment.

On 17 Apr., 22 weeks after beginning the treatments, the inorganic solute content of leaves was determined with dry mass in four plants per treatment. The concentration of $\mathrm{Cl}^{-}$ was analyzed by a chloride analyzer (Chloride Analyser Model 926; Sherwood Scientific Ltd., The Paddocks, Cambridge) in the aqueous extracts obtained when mixing $100 \mathrm{mg}$ of powdered dry vegetable with $40 \mathrm{~mL}$ of water before shaking for $30 \mathrm{~min}$ and filtering. The concentrations of $\mathrm{Na}^{+}, \mathrm{K}^{+}, \mathrm{P}, \mathrm{N}, \mathrm{Ca}^{2+}$, $\mathrm{Mg}^{2+}$, and $\mathrm{B}$ were determined in a digestion extract with $\mathrm{HNO}_{3}: \mathrm{HClO}_{4}(2: 1, \mathrm{v} / \mathrm{v})$ by inductively coupled plasma optical emission spectrometer (ICP-OES IRIS INTREPID II XDL; Agilent Technologies, Inc., Santa Clara, $\mathrm{CA}$ ). Total $\mathrm{N}$ was determined in four plants per treatment. For every plant, $\approx 0.1 \mathrm{mg}$ of dry leaf was weighed and ground before analyzing the $\mathrm{N}$ content in a Flash EA 1112 series thermo elementary analyzer (Thermo Fisher Scientific, Waltham, MA) by pure oxygen combustion and $\mathrm{N}$ separation. A thermal

Table 2. Biomass parameters at the end of experiment in euonymus plants irrigated with water from different sources.

\begin{tabular}{lrc}
\hline Growth parameters & \multicolumn{1}{c}{$\mathrm{C}$} & $\mathrm{RW}$ \\
\hline Leaf DW (g/plant) & $129.27^{* \mathrm{x}} \pm 33.06$ & $179.00 \pm 12.13$ \\
Root DW (g/plant) & $104.64^{*} \pm 13.21$ & $67.56 \pm 5.27$ \\
Total DW (g/plant) & $346.89 \pm 20.04$ & $359.61 \pm 24.86$ \\
Root/shoot ratio & $0.455^{*} \pm 0.056$ & $0.231 \pm 0.008$ \\
Total leaf number & $2,910.4 \pm 549.5$ & $3,321.4 \pm 653.0$ \\
Total leaf area $\left(\mathrm{cm}^{2}\right)$ & $15,053 \pm 2077$ & $20,409 \pm 2197$ \\
Leaf DW/total DW & $36.51^{*} \pm 2.05$ & $49.79 \pm 0.45$ \\
Root DW/total DW & $31.08^{*} \pm 2.62$ & $18.78 \pm 0.51$ \\
Height $(\mathrm{cm})^{\mathrm{y}}$ & $57.80^{*} \pm 1.70$ & $62.50 \pm 2.66$ \\
\hline
\end{tabular}

${ }^{\mathrm{z}}$ Data are mean \pm SD $(\mathrm{n}=3)$.

y Data are mean \pm SD $(n=10)$

${ }^{\mathrm{x}}$ Values within a row followed by $*$ indicate statistically significant differences at confidence $95 \%$ between treatments, according to Duncan's multiple range test.

$\mathrm{C}=$ control; $\mathrm{RW}=$ reclaimed wastewater; $\mathrm{DW}=$ dry weight. conductivity detector provided signals proportional to the total $\mathrm{N}$ concentration.

Chlorophyll content, fluorescence, and color parameters in leaves. On 17 Apr. 2012, 22 weeks after beginning the treatments, the chlorophyll content was assayed according to Inskeep and Bloom (1985) in the leaves of four plants per treatment. The extraction was made from $50 \mathrm{mg}$ of fresh material in $5 \mathrm{~mL}$ of $80 \%$ acetone in the dark at $4{ }^{\circ} \mathrm{C}$. The extract was read at 647 and 664 $\mathrm{nm}$ in an Uvikon 940 spectrophotometer (Kontron Instruments AG, Zürich, Switzerland). Chlorophyll fluorescence parameters were measured with the LI-COR 6400 equipped with a fluorometer (6400-40; LI-COR Inc., Lincoln, NE). The energy conversion efficiency in photosystem II $\left(\mathrm{F}^{\prime}{ }_{\mathrm{v}} / \mathrm{F}^{\prime}{ }_{\mathrm{m}}\right)$ was determined during the day in the same plants in which gas exchange was measured. The maximal photochemical efficiency of photosystem $\left(\mathrm{F}_{\mathrm{v}} / \mathrm{F}_{\mathrm{m}}\right)$ on the adaxial leaf surface was also measured once at predawn.

Twenty-two weeks after beginning the treatments, leaf color was measured with a Minolta CR-10 colorimeter (Nieuwegein, Netherlands), which provided the color coordinates lightness $\left(\mathrm{L}^{*}\right)$, chroma $\left(\mathrm{C}^{*}\right)$, and hue angle $\left(\mathrm{h}^{\circ}\right)$ (McGuire, 1992) using eight plants per treatment.

Water relations. Twenty-two weeks after beginning the treatments, the diurnal patterns of $g_{\mathrm{S}}, \mathrm{P}_{\mathrm{n}}$, and $\Psi_{\text {stem }}$ were determined from sunrise to sunset, every $\approx 1.5 \mathrm{~h}$ in five plants per treatment. Leaf $g_{S}$ and net photosynthesis were determined in leaves exposed to sunlight using a gas exchange system (LI-6400; LI-COR Inc.) fixing the conditions of $\mathrm{CO}_{2}$ concentration at $380 \mathrm{ppm}$, the photosynthetically active radiation at $1000 \mu \mathrm{mol} \cdot \mathrm{m}^{-2} \cdot \mathrm{s}^{-1}$, and the speed of the circulating air flow inside the system at $300 \mathrm{mmol} \cdot \mathrm{s}^{-1}$.

Stem water potential was estimated immediately in the leaves in which $g_{S}$ and $\mathrm{P}_{n}$ were measured, according to Scholander et al. (1965) using a pressure chamber (Model 3000; Soil Moisture Equipment Co., Santa Barbara, CA), placing the leaves in the chamber within $20 \mathrm{~s}$ of collection and at a pressure of $0.02 \mathrm{MPa} \cdot \mathrm{s}^{-1}$ (Turner, 1988). Leaves for measuring $\Psi_{\text {stem }}$ were taken from the north-facing side and were covered with aluminium foil for at least $2 \mathrm{~h}$ before measurements.

In addition, seasonal changes in $g_{S}$ and $P_{n}$ at midday were determined in six leaves per treatment once a week, as described previously. The $\psi_{\mathrm{S}}$ at full turgor $\left(\Psi_{100 \mathrm{~s}}\right)$ was also estimated throughout the experiment using excised leaves with their petioles placed in distilled water overnight to reach full saturation. Then, these leaves were frozen in liquid nitrogen $\left(-196{ }^{\circ} \mathrm{C}\right)$ and stored at $-30{ }^{\circ} \mathrm{C}$. After thawing, the $\Psi_{100 \text { s }}$ was measured in the extracted sap using a WESCOR 5520 vapor pressure osmometer (Wescor Inc., Logan, UT) according to Gucci et al. (1991).

Leaf hydraulic conductance and transpiration. Twenty-two weeks after beginning the treatments, the leaf hydraulic conductance $\left(\mathrm{K}_{\mathrm{s}}\right)$ was calculated in four plants per treatment using the formula: 


$$
K_{s}=E / \Psi_{\text {leaf }}-\Psi_{\text {stem }}
$$

where $E$ is the transpiration calculated as the difference between evapotranspiration (ET) and evaporation. The ET was determined by recording the weight losses in four pots per treatment, and the evaporation was determined in the same way in a representative plant from which all the leaves had been detached. $\Psi_{\text {leaf }}$ is the leaf water potential and $\Psi_{\text {stem }}$ is the stem water potential.

Canopy temperature. Twenty-two weeks after beginning the treatments, every $\approx 1.5 \mathrm{~h}$ from sunrise to sunset, the canopy temperature from eight plants per treatment was measured manually with a thermal imager (ThermaCam FLIR-e50 System, Inc., U.K.), which consisted of a $240 \times 180$-pixel line scan imager operating in the wavebands 7.5 to $13 \mu \mathrm{m}$ with a noise equivalent temperature difference of 0.05 at $30^{\circ} \mathrm{C}$ and an accuracy of $2{ }^{\circ} \mathrm{C}$ or $2 \%$ of the reading. Infrared (IR) images were taken from the sunlit side of the canopy (Jones et al., 2002). Background temperature was determined as the temperature of a crumpled sheet of aluminium foil in a similar position to the leaves of interest with the emissivity set at 1.0 (Jones et al., 2002). The emissivity for measurements of euonymus

Table 3. Leaf mineral content in euonymus plants irrigated with water from different sources 22 weeks after applying treatments.

\begin{tabular}{lcc}
\hline Leaf analyses & $\mathrm{C}$ & $\mathrm{RW}$ \\
\hline $\mathrm{B}\left(\mathrm{mg} \cdot \mathrm{kg}^{-1}\right)$ & $25.91 * \mathrm{y} \pm 0.70$ & $31.63 \pm 1.85$ \\
$\mathrm{Ca}\left(\mathrm{mg} \cdot \mathrm{kg}^{-1}\right)$ & $8,605 \pm 600$ & $10,903 \pm 1200$ \\
$\mathrm{Mg}\left(\mathrm{mg} \cdot \mathrm{kg}^{-1}\right)$ & $1,513^{*} \pm 100$ & $1,836 \pm 100$ \\
$\mathrm{Na}\left(\mathrm{mg} \cdot \mathrm{kg}^{-1}\right)$ & $1,500^{*} \pm 400$ & $3,297 \pm 600$ \\
$\mathrm{Cl}\left(\mathrm{mg} \cdot \mathrm{kg}^{-1}\right)$ & $10,224^{*} \pm 700$ & $13,050 \pm 100$ \\
$\mathrm{~K}\left(\mathrm{mg} \cdot \mathrm{kg}^{-1}\right)$ & $7,910^{*} \pm 0.06$ & $12,323 \pm 900$ \\
$\mathrm{P}\left(\mathrm{mg} \cdot \mathrm{kg}^{-1}\right)$ & $1,103^{*} \pm 100$ & $1,514 \pm 100$ \\
$\mathrm{Zn}\left(\mathrm{mg} \cdot \mathrm{kg}^{-1}\right)$ & $24.41 \pm 9.01$ & $21.44 \pm 1.53$ \\
$\mathrm{Fe}\left(\mathrm{mg} \cdot \mathrm{kg}^{-1}\right)$ & $27.39 \pm 7.70$ & $23.42 \pm 2.14$ \\
$\mathrm{Mn}\left(\mathrm{mg} \cdot \mathrm{kg}^{-1}\right)$ & $20.20 \pm 1.41$ & $23.28 \pm 1.81$ \\
$\mathrm{Cu}\left(\mathrm{mg} \cdot \mathrm{kg}^{-1}\right)$ & $1.50 \pm 0.48$ & $1.77 \pm 0.37$ \\
$\mathrm{~N}\left(\mathrm{mg} \cdot \mathrm{kg}^{-1}\right)$ & $10,184 * \pm 904^{*}$ & $13,630 \pm 1000$ \\
\hline
\end{tabular}

${ }^{\mathrm{z}}$ Data are mean \pm SD $(\mathrm{n}=4)$.

${ }^{y}$ Values within a row followed by * indicate statistically significant differences at confidence 95\% between treatments, according to Duncan's multiple range test.

$\mathrm{C}=$ control; $\mathrm{RW}=$ reclaimed wastewater; $\mathrm{B}=$ boron; $\mathrm{Ca}=$ calcium $; \mathrm{Mg}=$ magnesium $; \mathrm{Na}=$ sodium $; \mathrm{Cl}=$ chlorine; $\mathrm{K}=$ potassium; $\mathrm{P}=$ phosphorus; $\mathrm{Zn}=$ zinc; $\mathrm{Fe}=$ iron; $\mathrm{Mn}=$ manganese $; \mathrm{Cu}=$ copper $\mathrm{N}=$ nitrogen. leaves/canopies was set at 0.96 (Grant et al., 2006; Leinonen et al., 2006). Images were taken at a distance of $\approx 0.7 \mathrm{~m}$ from the canopy of interest and later processed with ThermaCam Explorer software (FLIR QuickReport) as previously described in the literature (Grant et al., 2006; Leinonen et al., 2006). Using the IR image software, sunlit portions of leaves were selected based on the corresponding visible images, which were corrected for spatial calibration drift by subtracting a corresponding reference image of an isothermal surface (the lens cap), as suggested in the literature (Grant et al., 2006; Jones et al., 2002).

Data analyses and statistics. Eighty plants were randomly distributed to two irrigation treatments (40 plants per treatment). The data were analyzed by one-way analysis of variance using Statgraphics Plus for Windows 5.1 software (StatPoint Technologies, Inc., Warrenton, VA). Ratio and percentage data were subjected to an arcsine square-root transformation before statistical analysis to ensure homogeneity of variance. Treatment means were separated with Duncan's multiple range test $(P \leq 0.05)$.

\section{Results}

Water analyses. Eight weeks after beginning treatments, the chemical properties of the irrigation waters were analyzed (Table 1). Although the control and RW waters showed similar $\mathrm{pH}$ values, the EC value of RW water was approximately four times higher than the EC value of control. Also, higher values of $\mathrm{B}, \mathrm{Ca}, \mathrm{K}, \mathrm{Mg}$, and $\mathrm{P}$ values were observed in the RW water. The $\mathrm{Na}^{+}$and $\mathrm{Cl}^{-}$values in this water were $\approx 11$ and 10 times higher, respectively, than in the control water (Table 1).

Measurements of growth and mineral content. At the end of the experiment, despite there being no differences in the total DW between treatments, the leaf DW of euonymus plants irrigated with RW was statistically higher, whereas the root DW was lower than in C plants (Table 2). Therefore, the leaf $\mathrm{DW} /$ total DW ratio increased, whereas the root/shoot ratio and root DW/total DW decreased in RW plants with respect to values in the $\mathrm{C}$ plants. In contrast, total leaf number and total leaf area showed no difference between irrigation treatments. Regarding the height, the $\mathrm{C}$ plants were shorter than RW plants (Table 2).

Table 4. Color parameters, chlorophyll content, and leaf hydraulic conductance in euonymus plants irrigated with water from different sources 22 weeks after applying treatments.

\begin{tabular}{lrr}
\hline Parameters & \multicolumn{1}{c}{ C } & \multicolumn{1}{c}{ RW } \\
\hline Luminosity & \multicolumn{1}{c}{} & $44.56 \pm 0.59$ \\
Chroma & $47.74^{* x} \pm 0.43$ & $20.31 \pm 0.86$ \\
Hue angle & $25.69^{*} \pm 0.64$ & $117.54 \pm 0.66$ \\
Chl a $\left(\mathrm{mg} \cdot \mathrm{g}^{-1} \mathrm{DW}\right)^{\mathrm{y}}$ & $115.08^{*} \pm 0.54$ & $2.59 \pm 0.15$ \\
$\mathrm{Chl} \mathrm{b}\left(\mathrm{mg} \cdot \mathrm{g}^{-1} \mathrm{DW}\right)$ & $2.12^{*} \pm 0.14$ & $0.87 \pm 0.05$ \\
$\mathrm{Chl} \mathrm{T}\left(\mathrm{mg} \cdot \mathrm{g}^{-1} \mathrm{DW}\right)$ & $0.72^{*} \pm 0.05$ & $3.46 \pm 0.20$ \\
$\mathrm{~K}_{\mathrm{s}}\left(\mathrm{mmol} \cdot \mathrm{m}^{-2} \cdot \mathrm{MPa}^{-1} \cdot \mathrm{s}^{-1}\right)^{\mathrm{y}}$ & $2.84^{*} \pm 0.18$ & $1.501 \pm 0.272$ \\
\hline
\end{tabular}

${ }^{\mathrm{z}}$ Data are mean $\pm \mathrm{SD}(\mathrm{n}=8)$

${ }^{y}$ Data are mean \pm SD $(n=4)$.

${ }^{\mathrm{x}}$ Values within a row followed by $*$ indicate statistically significant differences at confidence $95 \%$ between treatments, according to Duncan's multiple range test.

$\mathrm{C}=$ control; $\mathrm{RW}=$ reclaimed wastewater; $\mathrm{Chl}=$ chlorophyll; $\mathrm{K}_{\mathrm{s}}=$ leaf hydraulic conductance.
Twenty-two weeks after beginning the treatments, an increase in the $\mathrm{Na}^{+}, \mathrm{Cl}^{-}$, and $\mathrm{B}$ content of leaves was observed in RW, although $\mathrm{Mg}^{2+}, \mathrm{K}^{+}$, and $\mathrm{P}$ were also accumulated. Moreover, the total $\mathrm{N}$ concentration was higher in RW plants than in the control plants (Table 3).

Chlorophyll content, fluorescence, and color parameters in leaves. Twenty-two weeks after beginning the treatments, the leaf chlorophyll content (a, b, and total) was higher in RW plants than in the control plants (Table 4). Regarding color parameters, the luminosity and chroma were lower and the hue angle was higher in the RW plants than in the $\mathrm{C}$ plants (Table 4). The result was a more intense green color in leaves of the RW plants than in the control plants. No visual damage such as chlorosis or necrosis to plants was observed and the aesthetic value of the plants was not diminished.

Twenty-two weeks after beginning the treatments, the $\mathrm{F}_{\mathrm{v}}^{\prime} / \mathrm{F}^{\prime}{ }_{\mathrm{m}}$ fluorescence decreased in all plants as the day progressed with no statistical differences between treatments until $1400 \mathrm{HR}$, when the RW plants began to show higher $\mathrm{F}^{\prime}{ }_{\mathrm{v}} / \mathrm{F}^{\prime}{ }_{\mathrm{m}}$ values, which remained higher than in $\mathrm{C}$ plants until the end of the solar light (Fig. 1A). The maximum efficiency of PSII in dark-adapted leaves $\left(\mathrm{F}_{\mathrm{v}} / \mathrm{F}_{\mathrm{m}}\right)$ remained $\approx 0.8$ in all plants.

Plant water status and gas exchange. The $g_{\mathrm{S}}$ values in C plants were statistically higher than in RW plants between $0800 \mathrm{HR}$ and $1200 \mathrm{HR}$. In addition, a decrease in $g_{\mathrm{S}}$ was observed in the all plants between $0800 \mathrm{HR}$ and $1000 \mathrm{HR}$ (Fig. 1B). From midday, there were no significant differences between treatments in $g_{S}$ and the RW plants showed a tendency to recover their values with respect to the control plants. Similar behavior was found for the maximum photosynthesis rate, which showed a tendency to decrease as the morning progressed, but with no significant differences between treatments (Fig. 1C). The stem water potential decreased in both control and RW plants, reaching the lowest values between $1400 \mathrm{HR}$ and $1600 \mathrm{HR}$. However, the $\Psi_{\text {stem }}$ in the RW plants was almost always significantly lower than in the $\mathrm{C}$ plants during the day (with differences of 0.2 to $0.4 \mathrm{MPa}$ between treatments) (Fig. 1D).

Throughout the experiment, $g_{\mathrm{S}}$ and $\mathrm{P}_{\mathrm{n}}$ were similar for both treatments, except on a few occasions when the values in RW plants fell below those of C plants (Fig. 2A-B). The $\Psi_{100 \text { s }}$ was lower in RW plants than in C plants from Week 18 (Fig. 2C).

Leaf hydraulic conductance, canopy temperature, and transpiration. Twenty-two weeks after beginning the treatments, the leaf hydraulic conductance was lower in RW plants than in C plants (Table 4). The canopy temperature throughout the day was slightly higher in the RW plants with maximum differences between treatments between $0800 \mathrm{HR}$ and $1200 \mathrm{HR}$ (Fig. 3A). Gravimetric transpiration of both treatments increased in the central hours of the day. However, the transpiration rate was higher in $\mathrm{C}$ plants than 

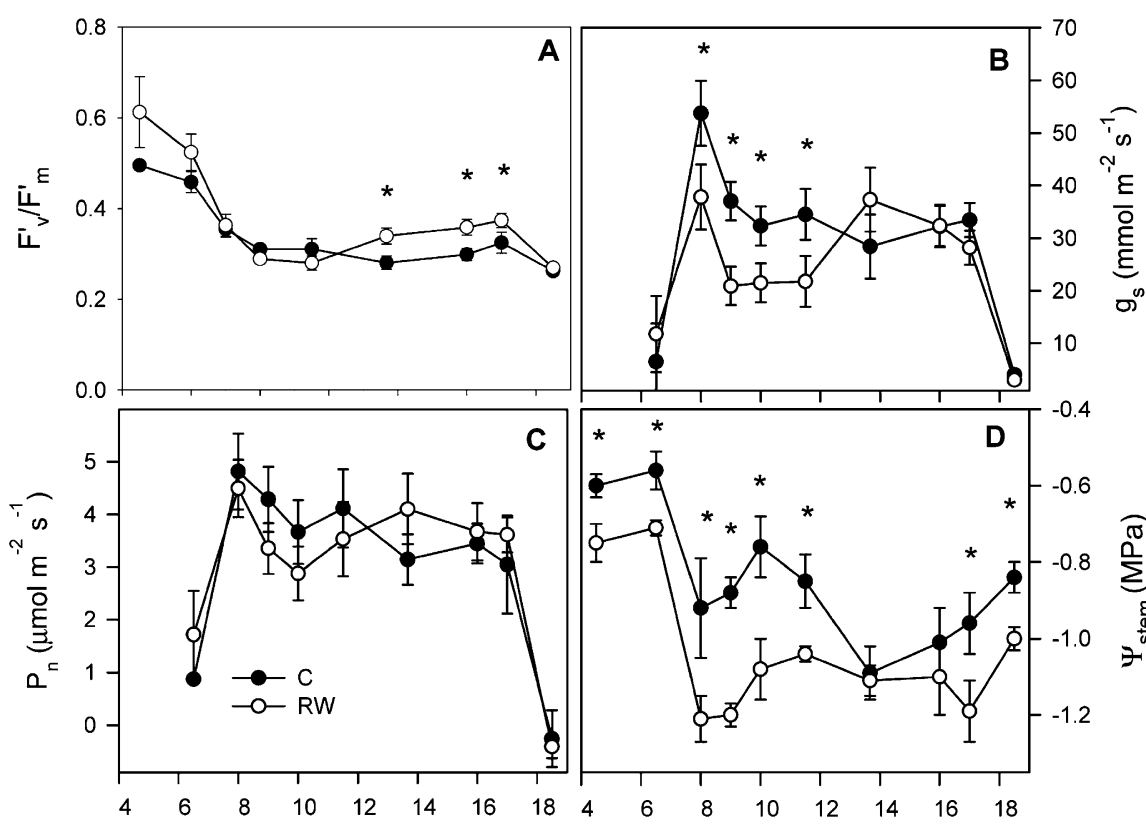

Solar time (hours)

Fig. 1. Daily evolution of fluorescence, $\mathrm{F}^{\prime}{ }_{\mathrm{v}} / \mathrm{F}^{\prime}{ }_{\mathrm{m}}(\mathbf{A})$, stomatal conductance $\left(g_{\mathrm{S}}\right)(\mathbf{B})$, net photosynthetic rate, $\mathrm{P}_{\mathrm{n}}(\mathbf{C})$, and stem water potential, $\Psi_{\text {stem }}(\mathbf{D})$, in euonymus plants irrigated with water from different sources 22 weeks after beginning the treatments. Values are mean of five plants. The vertical bars indicate sEs. Asterisks indicate statistically significant differences by Duncan ${ }_{0.05}$ test.
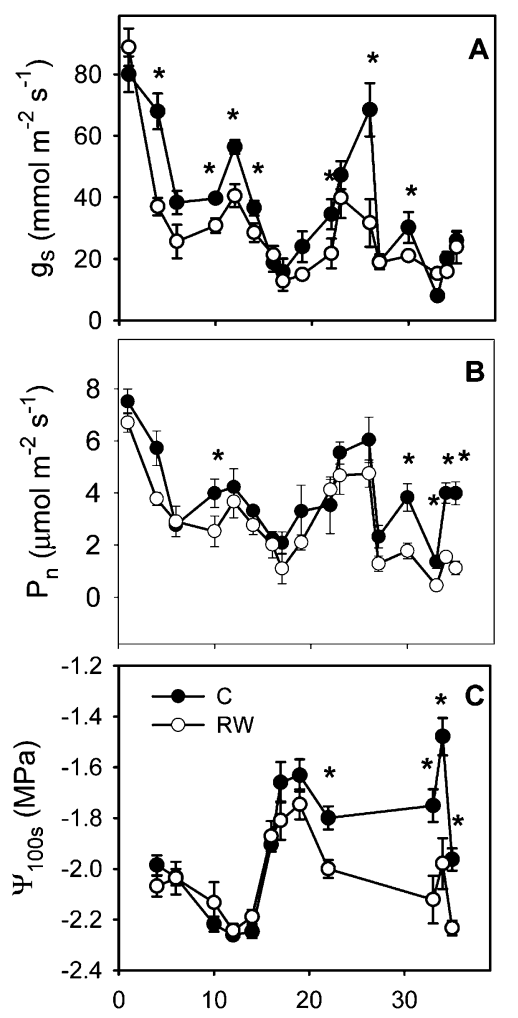

Time after beginning the treatments (weeks)

Fig. 2. Stomatal conductance $\left(g_{\mathrm{S}}\right)(\mathbf{A})$, net photosynthetic rate, $\mathrm{P}_{\mathrm{n}}(\mathbf{B})$ and osmotic potential at full turgor, $\Psi_{100 s}(C)$ at midday in euonymus plants irrigated with water from different sources throughout the experiment. Values are mean of six plants. The vertical bars indicate ses. Asterisks indicate statistically significant differences by Duncan $_{0.05}$ test. in RW plants during practically the whole day (Fig. 3B).

\section{Discussion}

The effect of using treated wastewater on the growth of ornamental species has been studied by many authors (Bañón et al., 2011; Gori et al., 2008; Lubello et al., 2004; Wu et al., 2001) with different results. In euonymus plants, the RW did not affect the total dry biomass at the end of experiment (Table 2). However, leaf DW increased in these plants probably because the nutrients synthesized were destined to the leaves, at the expense of the roots, whose DW decreased. This decrease in root dry mass could be explained by a mechanism to avoid the entrance of toxic ions. Similar results were found in Abutilon 'Kentish Belle' (Gori et al., 2000), Phlomis purpurea (Álvarez et al., 2012), and in Polygala myrtifolia (Bañón et al., 2011), although other authors have reported that shoot growth is more sensitive to salinity than the root part of the ornamental plants such as Lantana camara, Delosperma cooperi, and Teucrium chamaedrys (Bañón et al., 2011; Niu and Rodríguez, 2006). Thus, the excess salinity of reclaimed water may affect each part of the plant differently (Álvarez et al., 2012). In our previous study (Gómez-Bellot et al., 2013), euonymus plants irrigated with RW (from a sewage treatment plant in Campotejar, $\mathrm{EC}=4 \mathrm{dS} \cdot \mathrm{m}^{-1}$ and leaching of $30 \%$ ) showed decreased growth and a lower aesthetic value. However, in this case, our results are more in accordance with Miyamoto et al. (2004) who reported that euonymus is able to support 6 to $8 \mathrm{dS} \cdot \mathrm{m}^{-1}$, because the total growth in our plants was not negatively affected by salinity. Similar results were observed in cultivars of calla lilies (Veatch-Blohm et al., 2012).

The decrease in stem water potential (Fig. 1D) and in leaf hydraulic conductivity (Table 4) of plants irrigated with RW reflected their greater difficulty in absorbing water during the day than the control plants as a consequence of higher salt accumulation in the substrate (Álvarez et al., 2012). Regarding gas exchange, the most dramatic response to salinity is a decrease in stomata aperture (Munns and Tester, 2008), and as a consequence, $g_{\mathrm{S}}$ decreases. Although photosynthesis could also be the growth-limiting factor (Sánchez-Blanco et al., 2002), many species are able to maintain the photosynthesis rate unaltered despite reduced $g_{\mathrm{S}}$ (James et al., 2002) as occurred in our case (Fig. 1C). In addition, all the plants in our experiment showed decreased $g_{S}$ values between 0800 $\mathrm{HR}$ and $1000 \mathrm{HR}$ as well as lower $\mathrm{F}^{\prime}{ }_{\mathrm{v}} / \mathrm{F}^{\prime}{ }_{\mathrm{m}}$ values (Fig. 1A-B) between $0630 \mathrm{HR}$ and $1000 \mathrm{HR}$, probably as a result of limited stomatal aperture, because the temperature in the greenhouse increased during this period (Cameron et al., 2008). The same behavior was found by Petkova et al. (2007). Plants irrigated with reclaimed wastewater showed higher $\mathrm{F}^{\prime}{ }_{\mathrm{v}} / \mathrm{F}^{\prime}{ }_{\mathrm{m}}$ values than the control plants from $1400 \mathrm{HR}$ and the $\mathrm{F}_{\mathrm{v}} / \mathrm{F}_{\mathrm{m}}$ values indicated the absence of damage to the photosynthetic apparatus (Percival, 2005; Sixto et al., 2006).

Regarding seasonal gas exchange, the $g_{\mathrm{S}}$ and $\mathrm{P}_{\mathrm{n}}$ values (Fig. 2A-B) hardly showed any statistical differences between treatments during the experiment, and RW plants were able to maintain osmotic adjustment (Fig. 2C). It is well known that osmotic adjustment involves the net accumulation of solutes in a cell in response to salinity (Ghoulam et al., 2002). Consequently, the $\psi_{\mathrm{S}}$ decreases, which, in turn, attracts water into the cell and enables turgor to be maintained (Bradley and Morris, 1991).

On the other hand, the canopy temperature in RW plants (Fig. 3A) responded to the high temperature in the greenhouse and reflected the difficulty of plants to take water from the substrate during the day, as was evidenced by the stem water potential behavior in RW plants. The canopy temperature values were closely related to the stomatal opening, although the $g_{\mathrm{S}}$ values of euonymus plants were not excessively high in our conditions. As the plant transpires, the evaporation of water consumes heat energy, which decreases the leaf temperature and results in a cooling effect. The decrease of transpiration in RW plants led to an increase in the canopy temperature as a result of a reduction in the rate of heat removal (Colaizzi et al., 2012). Thus, the measurement of leaf temperature by thermal imaging can be regarded as a reliable way to detect changes in the physiological status of plants in response to abiotic stresses such as salinity (Sirault et al., 2009). 


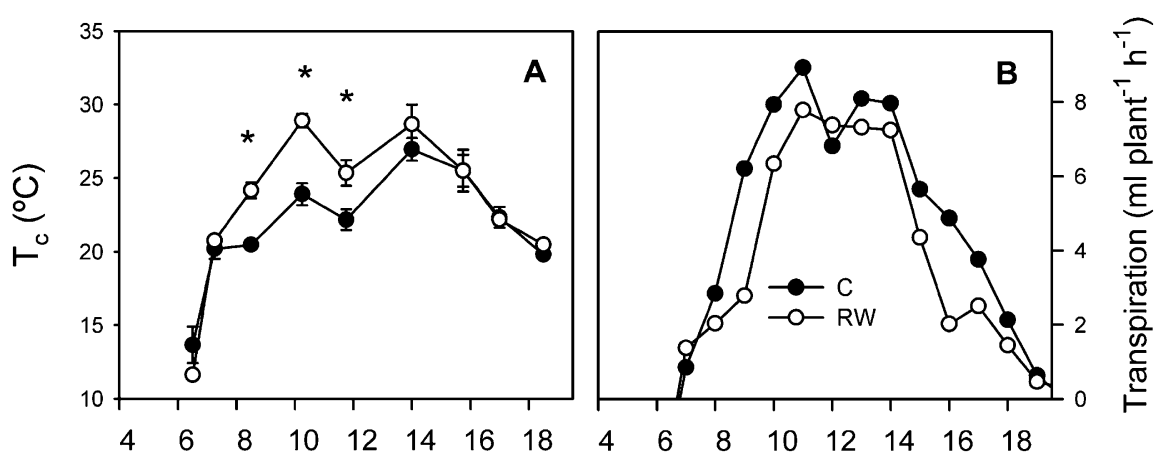

Solar time (hours)

Fig. 3. Daily canopy temperature, $T_{c}(\mathbf{A})$, and gravimetric transpiration $(\mathbf{B})$ in euonymus plants irrigated with water from different sources 22 weeks after beginning the treatments. Values from temperature are mean of eight plants. The vertical bars indicate sEs. Asterisks indicate statistically significant differences by Duncan ${ }_{0.05}$ test.

Toxic ions like $\mathrm{B}, \mathrm{Cl}^{-}$, and $\mathrm{Na}^{+}$were accumulated in leaves of the RW plants (Table 3) as a consequence of the water stream from the substrate to aerial tissues. Normally, the uptake of beneficial nutrients such as $\mathrm{Ca}^{2+}$ and $\mathrm{Mg}^{2+}$, which play an important role in cell structure, development, and plant metabolism, is often reduced in salt-sensitive plants grown in saline environments (Almansouri et al., 2001; Chaparzadeh et al., 2003). However, in our experiment, $\mathrm{Mg}^{2+}, \mathrm{K}^{+}, \mathrm{P}$, and total $\mathrm{N}$ were accumulated in leaves and $\mathrm{Ca}^{2+}$ was not reduced because of the greater amounts of these ions supplied with the wastewater. Similar results have been observed in Petunia hybrida and Calceolaria hybrida (Fornes et al., 2007). In addition, leaf $\mathrm{Cl}^{-}$concentration in RW plants was relatively low compared with other horticultural crops irrigated with low-quality water (Niu et al., 2010; Sun et al., 2013). Therefore, the salts present in the RW did not interfere in the absorption of $\mathrm{Mg}^{2+}, \mathrm{K}^{+}, \mathrm{P}$, $\mathrm{Ca}^{2+}$, and total $\mathrm{N}$, whose availability for the plant was maintained.

The increase in hue angle in RW plants produced leaves with a more intense green color, which was related with the higher chlorophyll (Table 4) and N content of these plants. Furthermore, the increase in fluorescence after midday and higher chlorophyll and $\mathrm{N}$ content of the RW plants could also be related to photosynthetic behavior (Evans and Poorter, 2001; Jiang and $\mathrm{Xu}, 2000$; Reich et al., 1995) and with a higher recovery capacity of these plants after midday. Salinity stimulates chlorophyll degradation and affects chlorophyll synthesis (Santos, 2004). However, these results indicate that $\mathrm{Cl}^{-}$and $\mathrm{Na}^{+}$were not concentrated enough in the leaves to cause photochemical damage. In contrast, the beneficial components from RW could increase the chlorophyll content and consequently helped maintain $\mathrm{P}_{\mathrm{n}}$ during growth. Salinity derived from RW may reduce growth and leaf expansion as a result of osmotic effects or toxicity, as we observed in a previous study in euonymus (Gómez-Bellot et al., 2013). However, the physiological response to RW throughout the day suggested that euonymus is resistant to these saline conditions, whereas the nutrients provided by the wastewater probably conferred benefits on the physiological function of the plant.

In this experiment, the plants showed no toxicity symptoms or loss of growth, and their aesthetic value was maintained. This response could be explained by: 1) the age of the plants and hence, a long acclimatization period in the greenhouse before the reclaimed wastewater treatment was imposed; 2) the higher leaching percentage than in the earlier experiment; and 3 ) the appreciable amounts of $\mathrm{Mg}^{2+}, \mathrm{Ca}^{2+}, \mathrm{K}^{+}$, and $\mathrm{P}$ contained in the wastewater, which could offset the toxic effects produced by high $\mathrm{B}, \mathrm{Na}^{+}$, and $\mathrm{Cl}^{-}$ concentrations, which in turn were lower in these conditions.

\section{Literature Cited}

Acosta-Motos, J.R., S. Álvarez, J.A. Hernández, and M.J. Sánchez-Blanco. 2014. Irrigation of Myrtus communis plants with reclaimed water: Morphological and physiological responses to different levels of salinity. J. Hort. Sci. Biotechnol. 89:487-494.

Almansouri, M., J.M. Kinet, and S. Lutts. 2001. Effect of salt and osmotic stresses on germination in durum wheat (Triticum durum Desf.). Plant Soil 231:243-254.

Álvarez, S., M.J. Gómez-Bellot, M. Castillo, S. Bañón, and M.J. Sánchez-Blanco. 2012. Osmotic and saline effect on growth, water relations, and ion uptake and translocation in Phlomis purpurea plants. Environ. Expt. Bot. 78:138-145.

Angelakis, A.N., M.H.F. Marekos, L. Bontoux, and T. Asano. 1999. The status of wastewater reuse practice in the Mediterranean basin: Need for guidelines. Water Res. 33:2201-2217.

Bañón, S., J. Miralles, J. Ochoa, J.A. Franco, and M.J. Sánchez-Blanco. 2011. Effects of diluted and undiluted treated wastewater on the growth, physiological aspects and visual quality of potted lantana and polygala plants. Sci. Hort. 129:869-876.

Bradley, P.M. and J.T. Morris. 1991. The influence of salinity on the kinetics of $\mathrm{NH}_{4}^{+}$uptake in Spartina alterniflora. Oecologia 85:375-380.

Cameron, R., R. Harrison-Murray, M. Fordham, S. Wilkinson, W. Davies, C. Atkinson, and M.
Else. 2008. Regulated irrigation of woody ornamentals to improve plant quality and precondition against drought stress. Ann. Appl. Biol. 153:49-61.

Chaparzadeh, N., R.A. Khavari-Nejad, F. NavariIzzo, and A. Izzo. 2003. Water relations and ionic balance in Calendula officinalis $\mathrm{L}$. under saline conditions. Agrochimica 47:69-79.

Colaizzi, P.D., S.R. Evett, S.A. O'Shaughnessy, and T.A. Howell. 2012. Using plant canopy temperature to improve irrigated crop management. In: Proc. 24th Annual Central Plains Irrigation Conf., 21-22 Feb., Colby, KS.

Costa, J.M., M.F. Ortuño, C.M. Lopes, and M.M. Chaves. 2012. Grapevine varieties exhibiting differences in stomatal response to water deficits. Funct. Plant Biol. 39:179-189.

Demetriou, G., C. Neonaki, E. Navakoudis, and K. Kotzabasis. 2007. Salt stress impact on the molecular structure and function of the photosynthetic apparatus-The protective role of polyamines. BBA-Bioenergetics 1767:272280.

Duncan, R.R., R.N. Carrow, and M.T. Huck. 2009. Turfgrass and landscape irrigation water quality: Assessment and management, p. 1338. CRC Press, Boca Raton, FL.

Evans, J.R. and H. Poorter. 2001. Photosynthetic acclimation of plants to growth irradiance: The relative importance of specific leaf area and nitrogen partitioning in maximizing carbon gain. Plant Cell Environ. 24:755-768.

Feigin, A., I. Ravina, and J. Shalhevet. 1991. Irrigation with treated sewage effluent, p. 18 31. In: Management for environmental protection. Advanced series in agricultural sciences. Springer-Verlag.

Fornes, F., R.M. Belda, C. Carrión, V. Noguera, P. García-Agustín, and M. Abad. 2007. Preconditioning ornamental plants to drought by mean of saline water irrigation as related to salinity tolerance. Sci. Hort. 113:52-59.

Ghoulam, C.F., F. Ahmed, and F. Khalid. 2002. Effects of salt stress on growth, inorganic ions and proline accumulation in relation to osmotic adjustment in five sugar beet cultivars. Environ. Expt. Bot. 47:139-150.

Gómez-Bellot, M.J., S. Álvarez, M. Castillo, B. Bañón, M.F. Ortuño, and M.J. Sánchez-Blanco. 2013. Water relations, nutrient content and developmental responses of Euonymus plants irrigated with water of different degrees of salinity and quality. J. Plant Res. 126:567-576.

Gori, R., F. Ferrini, F.P. Nicese, and C. Lubello. 2000. Effect of reclaimed wastewater on the growth and nutrient content of three landscape shrubs. J. Environ. Hort. 18:108-114.

Gori, R., C. Lubello, F. Ferrini, F.P. Nicese, and E. Coppini. 2008. Reuse of industrial wastewater for the irrigation of ornamental plants. Water Sci. Technol. 57:883-889.

Grant, O.M., M.M. Chaves, and H.G. Jones. 2006. Optimizing thermal imaging as a technique for detecting stomatal closure induced by drought stress under greenhouse conditions. Physiol. Plant. 127:507-518.

Gucci, R., C. Xilyannis, and J.A. Flores. 1991. Gas exchange parameters, water relations and carbohydrate partitioning in leaves of field-grown Prunus domestica following fruit removal. Physiol. Plant. 83:497-505.

Hsiao, T.C. 1993. Effects of drought and elevated $\mathrm{CO}_{2}$ on plant water use efficiency and productivity, p. 435-465. In: Jackson, M.D. and C.R. Black (eds.). Global environmental change. Interacting stresses on plants in a changing climate. NATO ASI series. Springer, New York, NY. 
Inskeep, W.P. and P.R. Bloom. 1985. Extinction coefficients of chlorophyll $a$ and $b$ in N,Ndimethylformamide and $80 \%$ acetone. Plant Physiol. 77:483-485.

Jackson, R.D., D.B. Idso, R.J. Reginato, and P.J. Pinter, Jr. 1981. Canopy temperature as a crop water stress indicator. Water Resour. Res. 17:1133-1138.

James, R.A., A.R. Rivelli, R. Munns, and S. Von Caemmerer. 2002. Factors affecting $\mathrm{CO}_{2}$ assimilation, leaf injury and growth in saltstressed durum wheat. Funct. Plant Biol. 29:1393-1403.

Jiang, H. and D.-Q. Xu. 2000. Physiological basis of the difference in net photosynthetic rate of leaves between two maize strains. Photosynthetica 38:199-204.

Jimenez-Cisneros, B. 1995. Wastewater reused to increase soil productivity. J. Water Sci. Technol. 32:173-180.

Jones, H.G., M. Stoll, T. Santos, C. Sousa, M.M. Chaves, and O.M. Grant. 2002. Use of infrared thermography for monitoring stomatal closure in the field: Application to grapevine. J. Expt. Bot. 53:2249-2260.

Kiziloglu, F.M., M. Turan, U. Sahin, I. Angin, O. Anapali, and M. Okuroglu. 2007. Effects of wastewater irrigation on soil and cabbage-plant (Brassica olerecea var. capitate cv. yalova-1) chemical properties. J. Plant Nutr. Soil Sci. 170:166-172.

Leinonen, I., O.M. Grant, C.P.P. Tagliavia, M.M Chaves, and H.G. Jones. 2006. Estimating stomatal conductance with thermal imagery. Plant Cell Environ. 29:1508-1518.

Lubello, C., R. Gori, F.P. Nicesse, and F. Ferrini. 2004. Municipal-treated wastewater reuse for plant nurseries irrigation. Water Res. 38:29392947.

McGuire, R.G. 1992. Reporting of objective colour measurements. HortScience 27:1254-1255.
Miyamoto, S., I. Martinez, M. Padilla, and A. Portillo. 2004. Landscape plant lists for salt tolerance assessment, p. 12. Texas A\&M Univ. Agri. Research Center at El Paso and El Paso Water Utilities, El Paso, TX.

Munns, R. and M. Tester. 2008. Mechanisms of salinity tolerance. Annu. Rev. Plant Biol. 59:651-681.

Neumann, P.M. 1997. Salinity resistance and plant growth revisited. Plant Cell Environ. 20:1193-1198.

Niu, G. and R.I. Cabrera. 2010. Growth and physiological responses of landscape plants to saline water irrigation-A review. HortScience 45:1605-1609.

Niu, G. and D. Rodríguez. 2006. Relative salt tolerance selected herbaceous perennials and groundcovers. Sci. Hort. 110:352-358.

Niu, G., D.S. Rodriguez, E. Call, P. Bosland, A. Ulery, and E. Acosta. 2010. Responses of eight Chile peppers to saline water irrigation. Sci. Hort. 126:215-222.

Percival, G.C. 2005. Identification of foliar salt tolerance of woody perennials using chlorophyll fluorescence. HortScience 40:18921897.

Petkova, V., I.D. Denev, D. Cholakov, and I Porjazov. 2007. Field screening for heat tolerant common bean cultivars (Phaseolus vulgaris L.) by measuring chlorophyll fluorescence induction parameters. Sci. Hort. 111:101-106.

Reich, P.B., M.B. Walters, B.D. Kloeppel, and D.S Ellsworth. 1995. Different photosynthesisnitrogen relations in deciduous hardwood and evergreen coniferous tree species. Oecologia 112:492-501.

Sánchez-Blanco, M.J., P. Rodríguez, M.A. Morales, M.F. Ortuño, and A. Torrecillas. 2002. Comparative growth and water relations of Cistus albidus and Cistus monspeliensis plants during water deficit conditions and recovery. Plant Sci. 162:107-113.
Santos, C.V. 2004. Regulation of chlorophyll biosynthesis and degradation by salt stress in sunflower leaves. Sci. Hort. 103: 93-99.

Scholander, P.F., H.T. Hammel, E.D. Bradstreet, and E.A. Hemingsen. 1965. Sap pressure in vascular plants. Science 148:339-346.

Schuch, U. 2005. Effect of reclaimed water and drought on salt-sensitive perennials. HortScience 40:1095 (abstr.).

Sirault, X.R.R., R.A. James, and R.T. Furbank. 2009. A new screening method for osmotic component of salinity tolerance in cereals using infrared thermography. Funct. Plant Biol. 36:970-977.

Sixto, H., I. Aranda, and J.M. Grau. 2006. Assessment of salt tolerance in Populus alba clones using chlorophyll fluorescence. Photosynthetica 44:169-173.

Sun, Y., G. Niu, P. Osuna, G. Ganjegunte, D. Auld, L. Zhao, J.R. Peralta-Videa, and J.L. GardeaTorresdey. 2013. Seedling emergence, growth, and leaf mineral nutrition of Ricinus communis L. cultivars irrigated with saline solution. Ind. Crops Prod. 49:75-80.

Turner, N.C. 1988. Measurements of plant water status by the pressure chamber technique. Irrig. Sci. 9:289-308.

Veatch-Blohm, M.E., M. Malinowski, and D. Keefer. 2012. Leaf water status, osmotic adjustment and carbon assimilation in colored calla lilies in response to saline irrigation. Sci. Hort. 144:65-73.

Weber, B., Y. Avnimelech, and M. Juanico. 1996. Salt enrichment of municipal sewage: New prevention approaches in Israel. Environ. Mgt. 20:487-495.

Wu, L., X. Guo, and A. Harivandi. 2001. Salt tolerance and salt accumulation of landscape plants irrigated by sprinkler and drip irrigation systems. J. Plant Nutr. 24:473-490. 